\title{
A great variety of transformations - and populisms
}

\author{
Floris Biskamp (floris.biskamp@uni-tuebingen.de) \\ University of Tübingen, Germany
}

Hans-Jürgen Bieling makes a convincing case that there are valuable lessons to be learned from Karl Polanyi's analyses of the rise of authoritarianism in the $20^{\text {th }}$ century to understand the rise of right-wing populism today. However, in order to realize the full potential of this approach, some ideas at the margins of his argument should be expanded and reworked. As I argue in this paper, this is particularly true for three aspects: First, the economic and social transformation processes to which Bieling refers differ strongly from region to region, fostering different kinds of populist mobilization. Second, the idea of a new cleavage is not fully convincing in the form in which Bieling presents it and should be reworked to account for at least two cleavages. Third, the notion of embeddedness must be understood as a multidimensional phenomenon to account for dynamics of gender and race - which then opens a pathway to overcoming the tired controversy over whether right-wing populism is about the economy or about culture and identity.

\section{A great variety of transformations: different gaps, different populisms}

Bieling's Polanyian account of the rise of right-wing populism goes as follows: Capitalist societies are always battlegrounds of a political struggle defined by two organizing principles or ideologies: the "principle of economic liberalism" and the "principle of social protection". In the last couple of decades, (not only) Europe witnessed an expansion of the former principle at the cost of the latter - which goes along with an historic process of neoliberalization, financialization, globalization, and Europeanization. The process of disembedding the market from institutions of social protection corresponding to this ideological shift causes increased insecurity and vulnerability among the population, which must be processed culturally, socially, and politically. Thus, the consequences of this process are contingent upon cultural processes of interpretation and political struggles; a turn towards authoritarian and nationalist interpretations is one possible reaction and thusly, right-wing mobilization has increased chances for success - particularly if the left is weak. This historiographic sketch is convincing, but it must be diversified geographically, which can be demonstrated with reference to the concept of a representation gap, which Bieling adopts from political science research - and then puts aside a little too quickly. There is a plausible connection between populist successes in general and gaps in political representation. According to Cas Mudde's widely-used definition, populism should be understood as:

"a thin-centered ideology that considers society to be ultimately separated into two homogeneous and antagonistic groups, 'the pure people' and 'the corrupt elite,' and which argues that politics should be an expression of the volonte générale (general will) of the people" (Mudde \& Rovira Kaltwasser, 2012, 8, italics in original).

Political mobilization building on such an ideology has the best chances of success if parts of the population do not feel represented within the current political system: groups who do not feel represented are most likely to be susceptible to a rhetoric of self-declared outsiders claiming that "the people" were forgotten by "the elites" (Mudde \& Rovira 
Kaltwasser, 2017, 101; Mair, 2009). While Bieling only refers to gaps on the left being exploitable by left-wing populism and gaps on the right being exploitable by right-wing populism, cross-mobilization is plausible: Social groups that traditionally felt represented by parties of the left but now feel abandoned by them can also be mobilized by right-wing populists (Eribon, 2013, 140-154). ${ }^{1}$

To explain populist successes then, one must ask which demographics do not (or more importantly: do no longer) feel represented by established non-populist parties and why this is the case. In the context of the Polanyian framework, one must ask how the processes of neoliberal disembedding cause some demographics to feel politically disenfranchised (be it for very good reasons or not).

In addressing this question, one must account for the fact that the processes of neoliberalization and globalization take very different forms in different regions, producing different gaps of representation and thereby different opportunity structures for populist mobilization - an argument brought forward by Rodrik (2018) and Werner (2013) in different terminologies. The difference is not only one of quantity, referring to the number of people not feeling represented. It is also one of quality, referring to the specific kinds of groups not feeling represented for specific reasons: By definition, Populism claims to speak for "the people" in general; however, each populist project must paint specific pictures of "the people" and the problems it faces. Accordingly, different groups will be attracted to different kinds of populist mobilization: Populists picturing "the people" as economically independent small entrepreneurs betrayed by an overbearing tax and welfare state will attract different voters than populists portraying "the people" as workers betrayed by globalist profit-seeking elites. Thus, different gaps in representation are exploitable by different kinds of populist projects. Populists portraying ethnic minorities as dangerous 'Others' are unlikely to have electoral success among these minorities etc.

And indeed, the picture of populist successes in Europe is truly heterogeneous. In general, Northern, Central, and Eastern Europe have strong right-wing populist projects while Southern Europe strong left-wing populist projects (Manow, 2018, 38-50); Anglo-Saxon countries seem to be open to both kinds of populism, as is France. If one looks at rightwing populism more closely, the heterogeneity becomes even greater. As Bieling notes, some parties such as the National Front/National Rally in France propagate an economic and social programme demanding an economically active state and high rates of redistribution - of course always in a nationalistic, exclusivist fashion. Bieling describes this as an overarching trend among right-wing populist parties in Europe shifting away from their economic liberalism of the 1980s and 1990s. Yet, the right-wing populist scenery remains much more heterogeneous. While the National Front/National Rally changed its economic position dramatically, the Swiss People's Party remains closer to the libertarian economic and social programme that was known as part of the "winning formula" of right-wing populism in the late $20^{\text {th }}$ century; the same is true for the Norwegian Progress Party. The Freedom Party of Austria deployed a rhetoric of defending the welfare state in recent years but engaged in policies of neoliberal reform as soon as they became part of the coalition government. Within Alternative for Germany, the conflict concerning the economic and social programme remains undecided at the beginning of 2019. Rather than a general trend towards a right-wing populism championing a strong, yet exclusive welfare state, Europe is witnessing a diversification of populism (Otjes et al., 2018).

The Polanyian approach must be expanded to account for this heterogeneity. The most plausible hypothesis is that the neoliberal transformation of European capitalism affected different regions in different ways, shifting the system of representation in specific forms, producing specific gaps in representation. These gaps open opportunities for specific kinds

\footnotetext{
${ }^{1}$ Bieling mentions this mechanism but not under the rubric of representation gap.
} 
of populist mobilization (Rodrik, 2018). Some offer better chances for left-wing populism, others for right wing populism with a pro-welfare-state agenda, others for right wing populism with an economically liberal agenda (Werner, 2013). Research into these dynamics has been relatively sparse so far. Philip Manow (2018) argues that the main independent variable explaining these differences is the type of welfare state undergoing the processes of neoliberalization and globalization. According to his argument, depending on the type of welfare state, different groups are opposed to different aspects of globalization: He argues that in welfare states of the northern and continental variant, trade is typically not considered a problem but migration is - and depending on the kind of migration being of concern different groups will be more likely to oppose it vehemently: labour market insiders oppose refugee migration, whereas labour market outsiders oppose work migration. In Mediterranean countries, with their rudimentary welfare states, migration is less of a problem - the more threatening aspect of globalization is the mobility of goods. Since the parties of the political mainstream are overwhelmingly pro-Europeanization and pro-globalization, all these attitudes are possible inroads for populist mobilization - but for different kinds of populist mobilization (Manow, 2018, 61-69).

Manow's research is an important step towards an explanation of the heterogeneity of populism in Europe, but some questions remain open. Most notably, his approach does not sufficiently explain the stark differences between Germany and France. ${ }^{2}$ Both countries are typically categorized as continental/conservative welfare-states, yet both have witnessed very different economic developments over the last 15 years and also feature very different populist dynamics, with only France having strong left-wing populist actors and a right-wing populist party with a clearly exclusivist pro-welfare state programme. The most plausible explanation for these divergent developments is to be found in the neoliberal reform programme of the Schröder government in Germany in the first years of the $21^{\text {st }}$ century, producing an edge in 'competitiveness' for Germany and a big current account surplus (also vis-à-vis France) exporting not only goods and services but also unemployment (specifically youth unemployment) and insecurity and thusly specific mobilization potentials for populism (Flassbeck \& Lapavitsas, 2013, 9-17). This implies that the developments in France and Germany are not only different, they are also interrelated - and the same is of course true for many other differences between countries.

Thus, the research programme suggested by Werner, Rodrik and Manow should be expanded, addressing more axes of politico-economic difference between countries and regions - including the dimensions of race and gender outlined below. This research can then align very well with Polanyian social theory, painting a picture of the heterogeneous and interdependent shapes that the processes of neoliberal disembedding take in different regions, producing different gaps in political representation and different opportunity structures for populist mobilization - nationalist-authoritarian and otherwise.

\section{A new cleavage - or two?}

The second concept from political science research Bieling takes up in his social theoretical approach is that of a new cleavage. Ever since Lipset and Rokkan introduced the concept of cleavages in the 1960s, there have been claims about new cleavages. Following some of these concepts, Bieling argues that the neoliberal transformation produces a new cleavage between (neo-)liberal cosmopolitanism and nationalist communitarianism. Two remarks are in place here:

First, it must be noted that, like many other conceptions of a new cleavage, Bieling's argument departs considerably from Lipset and Rokkan's original model: The four original

\footnotetext{
${ }^{2}$ Manow $(2018,106)$ remarks that France bears some resemblance to Southern states but does not fully explore the consequences.
} 
cleavages are defined by the position subjects hold within the social structure. ${ }^{3}$ Many of the newly hypothesized cleavages, however, refer to the ideological orientation subjects have. Of course, it can be argued that this shift of perspective is necessary to reflect upon changes in social relations. Yet, it begs the question of how these ideologically defined cleavages relate to social positions - this is particularly true since the "old" cleavages can still be very useful to analyse right-wing populism (Kempin, 2017). So: Which kind of economic position, occupation, living condition, education, geography and so on foster certain ideological orientations towards neoliberalism and cosmopolitanism? Kitschelt and others describe a relation between the type of professional occupation subjects have and their inclination towards more liberal or authoritarian, cosmopolitan or nationalistic attitudes (Kitschelt, 2017; Kitschelt \& Rehm, 2014). If one follows this argument, the shifts in the sectoral composition of economies that go along with globalization processes could contribute to the emergence of new cleavages. Such considerations could then also help integrating the concept of a new cleavage with the Polanyian framework.

Second, it does not seem convincing that there is one cleavage between (neo-)liberal cosmopolitanism on the one side and nationalist communitarianism on the other side. Rather, what Bieling identifies as one new cleavage appears to be two distinct fault lines: There is one ideological split between the proponents of neoliberalism and those of a strong, economically active welfare state; there is another ideological split between the proponents of liberal cosmopolitanism and diversity and those of authoritarian nationalism and traditionalist communitarianism. ${ }^{4}$ When making an argument concerning political philosophy, one might argue that some combinations are more coherent than others; but when addressing social reality, there is no a priori reason to assume that the two fault lines are congruent, creating only two distinct camps. Rather, they allow for four different ideological positions: neoliberal-cosmopolitanism, neoliberal-nationalism, pro-welfare cosmopolitanism, and pro-welfare nationalism. And indeed, there are political projects in all four of these camps. In Germany, for example, large parts of Alternative for Germany remain nationalistic and neoliberal (the same is true for the supporters of the Tea Party in the United States) while a majority of the party The Left remains pro-welfare state and cosmopolitan (the same is true for many supporters of Sanders in the United States). ${ }^{5}$ The Free Democratic Party in Germany is cosmopolitan and neoliberal, while the right-wing extremist "Flügel" within Alternative for Germany is pro-welfare nationalist. Of course, it is possible that these parties misrepresent the attitudes of the population. Moreover, one might argue that the supporters of pro-welfare cosmopolitanism are de facto still products of a neoliberal economy or that their claims are incoherent. But still, the political landscape is not defined by one cleavage between (neo-)liberal cosmopolitanism and nationalist communitarianism. Thus, the question of new cleavages must be reassessed.

\footnotetext{
${ }^{3}$ This is least obvious in the case of the religious/secular-cleavage. Yet, being a religious citizen in a strong sense does not only mean having a certain creed and ideological orientations, it also means being situated within a particular religious community and its institutional structures.

${ }^{4}$ Looking more closely, one could differentiate even further, distinguishing more lines of conflict: One could differentiate first between economic positions promoting state interventionism and a strong welfare state and positions promoting an economically weaker, less distributive state; second between economic positions with a more nationalist and protectionist outlook and positions promoting free trade and globalization (Trump stands for a programme against the welfare-state and against free trade); third between political cosmopolitanism and communitarianism/nationalism; and fourth between cultural liberalism and authoritarianism. The intersection of these differences in four dimensions would already allow for sixteen different positions - and of course this list could be continued.

${ }^{5}$ Even the undoubtedly cosmopolitan Greens in Germany can hardly be categorized as straightforward neoliberal, if one takes the economic and social policy positions of the party manifesto at face value - which of course have rather low salience for the party.
} 


\section{Embeddedness as a multidimensional phenomenon}

\subsection{Qualitative transformations of embeddedness}

A particularly promising aspect of Bieling's Polanyian approach is its potential to overcome the tired controversy between cultural and economic interpretations of right-wing populism. Bieling argues that the economic transformations since the 1970s have had a strong impact on social relations and thereby have prepared the grounds for the rise of right-wing populism. However, he also emphasizes that such political effects of economic development are never direct and inevitable but always mediated by and contingent upon sociocultural interpretation and conflict, which includes politics of culture and identity.

Yet, there are some elements of the Polanyian approach that need to be questioned and expanded to live up to this potential. The most problematic is the implication of one-dimensionality that results from metaphorizing the double movement as a pendulum swinging between the two organizing principles of economic liberalism and social protection: An ideal (i.e. frictionless) pendulum moves back and forth between two positions, not changing its qualities and passing the same locations the same way over and over again. Society does not. ${ }^{6}$ Bieling addresses this problem in the economic realm, explaining that there has not only been a one-dimensional back-and-forth development of capitalism but that the very nature of capitalism underwent qualitative transformations over the course of decades and centuries.

The same is true for many institutions of society that the market economy is embedded in: The market economy is not only more or less embedded in institutions of social protection; these institutions as well as the nature of embeddedness transform qualitatively over time. This could be discussed with many examples. Since these two areas are central to right-wing populist mobilization (Hochschild, 2016, 135-151) but marginal to Bieling's argument, I will sketch the argument concerning gender (3.2) and race/ethnic (3.3) relations. ${ }^{7}$ Finally I address the question of "progressive neoliberalism" (Fraser 2017) (3.4).

\subsection{Gender relations}

In Western societies, the nuclear family has a central place among the social institutions embedding the market in society and granting social protection. From an economic standpoint, the most crucial function of the family is the reproduction of labour without which the market economy could not exist: In the short run, the immediate physiological and social needs of the individual wage labourers must be met, in the long run the supply of new generations of wage labourers must be ensured, and moreover, the elderly who cannot provide for themselves anymore must be taken care of - and for all three functions, the nuclear family plays a central role. Thereby, this private sphere of the family is also a central institution of social protection. Economic hardships experienced by some individuals can be ameliorated with assistance from family members, the elderly can be cared for by their children or children in law, and grandparents can assist in bringing up the young. However, the according processes are highly gendered, requiring great amounts of unpaid reproductive or care work performed disproportionately by women - which is not to say that women do not also perform wage labour. Therefore, this gendered division of labour requires and constitutes a form of institutionalized subordination of women under men within the family and a (partial) exclusion from the public sphere and the formal economy. The women that did participate in the labour market during the heyday of the post-war welfare-state were often marginalized in less secure and worse paid positions - to

\footnotetext{
${ }^{6}$ Physics allows for a pendulum swinging in multiple dimensions. Metaphors typically do not. And even a Pendulum swinging in two dimensions at the same time will repeat the same movements over and over again cyclically, society still does not.

${ }^{7}$ Bieling (2012) discusses the developments of gender and race/ethnicity in financialized capitalism elsewhere.
} 
different degrees in different welfare-state regimes. This subordination and exclusion can only work, if it is constantly reproduced and reinscribed in everyday practice and culture i.e. by politics of gender identity. Thus, not only the nuclear family but also the formal economy and the welfare state themselves are gendered institutions, distributing social protection unevenly. ${ }^{8}$

The institution of the nuclear family was weakened and became more flexible in the last third of the $20^{\text {th }}$ century. Many women, particularly from the middle classes, were able to reduce their load of reproductive and care work and now have a greater presence on the labour market as well as in the public sphere. This was made possible not only by political struggles attacking the juridical and non-juridical norms legitimizing the subordination of women, but also by technological progress and by outsourcing care work to (under-)paid care-workers - mostly female and often migrant and/or racialized subjects (Ehrenreich \& Hochschild, 2004).

One might claim that these transformations constitute a swing of the pendulum from the side of social protection towards the side of economic liberalism and thusly a process of disembedding: Women that used to be occupied within the households became available to the labour market and activities that were formerly organized outside the market are now provided by the market or by public institutions - by individual (disproportionately migrant) care and domestic workers, by companies employing them, by public kindergartens, by nursery services etc. Of course, weakening the institution of the nuclear family also means weakening its embedding and protecting function. Thus, some authors interpret this transformation as a process of market expansion - or put in Polanyian terms: disembedding. This is true for authors as different as Wolfgang Streeck and Jürgen Habermas. In his historiographic sketch of capitalist crises, Streeck $(2014,29-30,39)$ deploys an argument of false consciousness, criticizing women for wrongly celebrating their partial transition from their role in the nuclear family to the public sphere and the labour market. Streeck reads this process not as emancipation from patriarchy but as absorption by the market economy where the newly arriving women became "allies of the employers" (29). Thirty years before Streeck, Habermas (1987, 319, 368-373, 386-389) famously interpreted earlier, yet similar transformations of the family as a "colonization of the life world" by systems forces - the logics of capitalist economy and state administration. ${ }^{9}$

Yet, as feminist scholars have long argued, such interpretations do not hold (Fraser, 1995). The gendered institution of the nuclear family cannot simply be considered an institution of social protection because women suffer subordination, dependency, and thusly a drastic lack of protection within this institution. Subjects with sexual and gender identities beyond the heteronormative frame were excluded from this frame and the protection it offered all along - and the welfare state had ambiguous effects.

On the other hand, the fact that Other (mostly migrant and/or racialized) women are filling the care gap and suffer from new kinds of vulnerability, renders any interpretation of these processes as a straightforward feminist success story cynical and particularistic.

All in all, then, there is no reason to romanticize the nuclear family as an institution of social protection unfettered by marked logic as it is implicit in Streeck's argument. The weakening of this institution cannot simply be described as a swing of the Polanyian pendulum towards economic liberalism - this is true even though the institutions of the nuclear family and the (gendered) welfare state are strongly interwoven and the changes of the one went hand in hand with that of the other. If one addresses the process of

\footnotetext{
8 The role of the family varies (not only) from country to country. For the relation between different types of welfare state and different types of familialism see Leitner (2003).

${ }^{9}$ Habermas refers to the expansion of the welfare state in the third quarter of the $20^{\text {th }}$ century, Streeck refers to the expansion of the market in the last quarter. Yet their arguments concerning the effects on family relations are similaras is their omission of the patriarchal character of the nuclear family.
} 
disembedding that took place since the 1970s, one should address it in relation to the changes of family structures and thereby account for the qualitative transformation of the institutions of social protection in which the market economy is embedded.

Then, the interpretation of right-wing populism as a reaction to the double movement must be rephrased accordingly. The narrative can no longer simply be that a process of disembedding causes insecurity among the population and subsequently sparks authoritarian protest. One must also discuss - in terms of gender and class - which specific groups lost and gained specific forms of social protection, how these losses and gains relate to one another and how the differently affected groups react to the changes. Since right-wing populist voters are disproportionally male, it seems plausible to interpret the recent rightwing successes - among other things - as protests against these qualitative transformations in the embeddedness. The analysis of social transformation and populism must be gendered (Mudde \& Rovira Kaltwasser, 2015; Mayer et al., 2018; Dowling, van Dyk \& Graefe, 2017).

\subsection{Race and ethnic relations}

To address the dynamics of race, ethnicity, and migration, one must make an argument that is similar but not fully analogous to that concerning gender relations.

To conceptualize the embeddedness of the market, Bieling refers to E.P. Thompsons notion of the moral economy. But as Gurminder Bhambra and John Holmwood point out in their interpretations of Thompson and Polanyi, this moral economy was always already racialized and intertwined with (post)colonial power structures - and so are the institutions in which the market is embedded (Bhambra \& Holmwood, 2018; Holmwood, 2016). Race relations of course are very different from gender relations: In European countries of the $20^{\text {th }}$ century, they were typically not organized in the form of an institution such as the nuclear family in which a small number of people of different races/ethnicities would have very close relations of direct dependency. Moreover, these relations differ nationally and regionally: In the United States where they significantly rest on the difference between former black slaves and former free whites, they are different than they are in countries where the difference is honed by more recent processes of migration.

Nonetheless, in all cases these relations are deeply intertwined with the institutions of social protection, shaping the concrete forms of embeddedness. In many instances, racialized groups serve as a labour reserve that can be hired and fired more easily than white workers - similar to women. Such a racial division of the labour force strengthens the position of employers vis-à-vis workers; however, it also protects white/majoritarian workers and employees from some immediate effects of crises which are deflected towards racialized subjects who are the first to lose their jobs. Organized labour played an ambivalent role, at times actively affirming this division of the labour force, effectively representing established white workers rather than workers in general, at other times being solidary and inclusive or being transformed by self-organized non-white workers. ${ }^{10}$ Thus, the insider privilege often going along with the welfare state of the $20^{\text {th }}$ century to some degree tends to take the form of white privilege. The distinctions of race and ethnicity on which these privileges rest are not naturally given but socially constructed; thus, their reproduction requires a constant process of reinscription in everyday life and public discourse - i.e. politics of racial/ethnic identity (Bhambra, 2017; Bhambra \& Holmwood, 2018; Lüthje \& Scherrer, 2001).

Similar to the gendered division of labour, the racial structure of the labour market and other institutions never disappeared, but it transformed and became more informalized

\footnotetext{
${ }^{10}$ These dynamics around race, labour, and migration are best researched concerning the United States (e.g. Scherrer \& Lüthje, 2001); for case studies concerning Germany see Huwer (2013) and Schröder (2015), for an overview see Trede (2016).
} 
and permissive over the decades. And just like in gender relations, these transformations in race and ethnic relations can hardly be interpreted as a simple swing of a pendulum from the direction of social protection to that of the free market. They correspond to a process of neoliberal disembedding, but they cannot be reduced to it. Rather, one also must account for the qualitative changes of embeddedness having different effects for different groups. An institutionalized division of the labour market shielding some groups from the woes of the market by disproportionately deflecting them to others has been weakened. Just like in gender relations, the groups that were shielded by this institution disproportionately vote for right-wing populism, while the groups that were subordinated by this institution disproportionately vote against it. Thus, it seems plausible that rightwing populism is - among other things - a protest against this qualitative transformation of embeddedness (Bhambra, 2017).

\subsection{Not an either-or}

This is emphatically not an argument against economic/class based and for cultural/identity-based interpretations of right-wing populism. Rather it is an argument for taking both interpretations seriously, which requires conceptualizing capitalism, race, and gender as deeply intertwined institutions: All actually-existing forms of capitalism have been gendered and racialized; all gender relations in modern societies have been racialized and interwoven with the logics of capitalism; all race relations in modern societies have been gendered and interdependent with capitalism. Any change in one of these institutions tends to be connected to changes in the others and should be analysed accordingly. Taking all three dimensions seriously also means taking them seriously in their contradictions and tensions - particularly the dynamics of welfare state and migration leave no room for a simple morally and politically virtuous position.

Thus, my argument that the transformations of gender and race relations of recent decades cannot be reduced to processes of disembedding does not imply that all three processes cannot or did not go together - but that they should be analytically distinguished. Most crucially, in their liberal forms focused on "diversity", politics of anti-sexism and antiracism can be deployed to give neoliberal policies of disembedding a progressive ring and make them acceptable among moderate left voters - these are the politics Fraser (2017) dubs "progressive neoliberalism". These "progressive" policies are particularly paradoxical and cynical insofar as women and racialized subjects are oftentimes disproportionately affected by neoliberal reform.

Yet, one should be cautious about two common mistakes: First, one should not reduce feminist and anti-racist politics to their neoliberal variant and then blame them for the rise of right-wing populism as it routinely happens in discourses around "identity politics" (Lilla, 2017; as a critique Dowling, van Dyk \& Graefe, 2017). Racism and patriarchy are realities of the market economy itself as well as of the social institutions it is embedded in - policies addressing these realities are not per se attacks on embeddedness itself, although they have been regularly mobilized for such attacks. Second, one should not pit explanations of right-wing populism as a protest against neoliberal disembedding and explanations of right-wing populism as a defence of (relative) male and white privilege against one another as it is routinely done from both sides. Neoliberal disembedding is a reality as is the relative decline of male and white privilege. Since the same populations are affected by these developments, it is likely that they are processed within the same cultural interpretation and political mobilization processes. The research of right-wing populist discourses and the everyday consciousness of right-wing populist voters and activists supports such an interpretation as a reaction to transformation of the formal economy and of gender and race relations (Hochschild, 2016; Koppetsch, 2018). 
In summary, the Polanyian approach suggested by Bieling can help interpreting and explaining the rise of right-wing populism as a reaction to processes of transformation - but to this purpose it should be able to account for the geographic heterogeneity of capitalism and its transformations; it should take the complexity of current political fault lines seriously; and it should consider embeddedness, its transformations, and the political protest against these transformations as multidimensional phenomena that are always gendered and racialized. After the grounds have been analysed, the questions of greatest strategic importance must be addressed: First, further research into the dynamics of authoritarian mobilization is required to understand under which circumstances and by which mechanisms experiences of insecurity are interpreted in authoritarian and nationalistic frames. Second, it is important to understand what other kinds of non-authoritarian mobilization could mobilize the same groups for different purposes. Third, it must be asked what kind of economic and social policies could and should be pursued to overcome the capitalist crises underlying the transformation processes of the last decades: Mobilizing populations without a political economic programme that will benefit them is no sustainable strategy - and there are good reasons to be sceptical about the possibility of returning to post-war Keynesianism (Streeck, 2014; 2017).

\section{References}

Bhambra, G.K. (2017). Locating Brexit in the pragmatics of race, citizenship and empire. In W. Outhwaite (Ed.), Brexit: Sociological Responses (91-100). London: Anthem Press.

Bhambra, G. K. \& Holmwood, J. (2018). Colonialism, postcolonialism and the liberal welfare state. New Political Economy, 23(5), 574-587.

Bieling, H-J. (2012). Transnationale (Krisen-)Dynamiken des Finanzmarktkapitalismus Klassenverhältnisse, Gender und Ethnizität aus politökonomischer Perspektive. Berliner Zeitschrift für Soziologie, 22(1), 53-77.

Bieling, H-J. (2019). Rise of right-wing populism in the Europe of today - outlines of a sociotheoretical exploration. Culture, Practice \& Europeanization, 4(1), 78-91.

Dowling, E., van Dyk, S. \& Graefe, S. (2017). Rückkehr des Hauptwiderspruchs. Anmerkungen zur aktuellen Debatte um den Erfolg der Neuen Rechten und das Versagen der ,Identitätspolitik'. Prokla, 188, 411-420.

Ehrenreich, B. \& Hochschuld, A.R. (Eds.) (2004). Global woman: Nannies, maids, and sex workers in the new economy. New York, NY: Owl Books.

Eribon, D. (2013). Returning to Reims. Cambridge, MA: MIT Press.

Flassbeck, H. \& Lapavitsas, C. (2013). The systemic crisis of the Euro - true causes and effective therapies. Berlin: Rosa Luxemburg Foundation.

Fraser, N. (1995). What is critical about critical theory? In J. Meehan (Ed.), Feminists Read Habermas. Gendering the Subject of Discourse. New York, NY: Routledge. 
Fraser, N. (2017). The end of progressive neoliberalism. https://www.dissentmagazine.org/online_articles/progressive-neoliberalism-reactionary-populism-nancy-fraser [2018-10-18].

Habermas, J. (1987). The Theory of Communicative Action. Volume 2. Lifeworld and system: A critique of functionalist reason. Boston: Beacon.

Hochschild, A. R. (2016). Strangers in their own land. Anger and mourning on the American right. New York, NY: The New Press.

Holmwood, J. (2016). From political economy to moral economy: Provincialising Polanyi. In C. Karner \& B. Weicht (Ed.), The Commonalities of Global Crises: Markets, Communities and Nostalgia. London: Palgrave Macmillan.

Huwer, J. (2013). „Gastarbeiter“ im Streik. Die Arbeitsniederlegung bei Ford Köln im August 1973. Köln: edition DOMiD.

Kempin, R. (2017): Der Front National. Erfolg und Perspektiven der ,stärksten Partei Frankreichs'. SWP-Studie, 2017/S 06.

Kitschelt, H. (in collaboration with A.J. McGann) (2017) [1995]. The contemporary radical right: An interpretative and explanatory framework. In C. Mudde (Ed.), The Populist Radical Right. A Reader. New York, NY: Routledge.

Kitschelt H. \& Rehm P. (2014). Occupations as a site of political preference formation. Comparative Political Studies, 47(12), 1670-1706.

Koppetsch, C. (2018). 'Rechtspopulismus als Klassenkampf? Soziale Deklassierung und politische Mobilisierung' WSI-Mitteilungen, 71(5), 382-391.

Leitner, S. (2003). Varieties of familialism. The caring function of the family in comparative perspective. European Societies, 5(4), 353-375.

Lilla, M. (2017). The once and future liberal: After identity politics. New York, NY: HarperCollins.

Manow, P. (2018). Die politische Ökonomie des Populismus. Berlin: Suhrkamp.

Mayer, S, Šori, I, Sauer, B. \& Ajanović, E. \& Sauer, B. (2018). Mann, Frau, Volk. Familienidylle, Heteronormativität und Femonationalismus im europäischen rechten Populismus. Feministische Studien, 36(2), 269-285.

Mudde, C. \& Rovira Kaltwasser, C. (2012). Populism and (liberal) democracy. A framework. In C. Mudde \& C. Rovira Kaltwasser (Eds.), Populism in Europe and the Americas. Threat or Corrective for Democracy? (1-26). Cambridge, UK: Cambridge University Press.

Mudde, C. \& Rovira Kaltwasser, C. (2015). Vox populi or vox masculini? Populism and gender in Northern Europe and South America. Patterns of Prejudice, 49(1-2), 16-36.

Mudde, C. \& Rovira Kaltwasser, C. (2017). Populism. A very short introduction. Oxford, UK: Oxford University Press. 
Rodrik, D. (2018). Populism and the political economy of globalization. Journal of International Business Policy, 1(1), 12-33.

Scherrer, C. \& Lüthje, B. (2001). Race, multiculturalism, and labour organising in the United States. Lessons for Europe. Capital \& Class, 73, 141-17.

Schröder, B. (2015). Gewerkschaften und Wanderarbeit. Von Saisonarbeit, Werkverträgen und migrantischer Organisierung in der Baubranche und im Grünen Bereich. Münster: Westfälisches Dampfboot.

Otjes, S., Ivaldi, G. Ravik Jupskås, A. \& Mazzoleni, O. (2018). It's not economic interventionism, stupid. Reassessing the political economy of radical right-wing populist parties. Swiss Political Science Review, 24(3), 270-290.

Streeck, W. (2014). Buying time. The delayed crisis of democratic capitalism. London: Verso.

Streeck, W. (2017). How will capitalism end? Essays on a failing system. London: Verso.

Trede, O. (2016). Gewerkschaften und Arbeitsmigration in der Bundesrepublik - zwischen Misstrauen und Integration. www.bpb.de/232789 [2019-01-05].

Werner, A. (2013). Rechtspopulistische Opposition in der Eurokrise. Das Argument, 301, 240-250. 